\title{
A MAGYAR ETNIKAI TÉRBELISÉG JELLEMZŐI AZ 1910-ES ANYANYELVI STATISZTIKAI ADATOK ALAPJÁN
}

Characteristics of the ethnic spatiality of the Hungarians based on the mother tongue statistics in 1910

\section{CSÜLLÖG GÁBOR}

Eötvös Loránd Tudományegyetem Földrajz- és Földtudományi Intézet Környezet- és Tájföldrajzi Tanszék g.csullog@gmail.com

\begin{abstract}
In the Austrian-Hungarian Monarchy there were permanent controversies on the ethnic problems and in these discussions the notions of "clean ethnic space" and "language border" played important role. They were emphasised especially by the nationalities of the Monarchy which were getting into advantageous political situation towards the end of the 1st World War. Partly by appreciation of necessity also the Hungarian politics found in these approaches the perspectives for the territorial defence; however, by this manner the presentation of the Hungarian ethnic weight - which was considerable in the administrative centres beyond the "language border" - has been given up. Unfortunately, the detailed surveys of this aspect were mostly missing both from the pre- and the post-Trianon analyses. Therefore, it is worth introducing some less known characteristics of the data regarding the ethnic composition.
\end{abstract}

Keywords: ethnicity, mother tongue, language border, Trianon Treaty, ethnic statistics

\section{BEVEZETÉS}

A 20. század elején a statisztikai kiadványokban megjelenő népességi adatok feldolgozása mind a magyarság, mind a nemzetiségek oldaláról rendszeres volt, különösen az I. világháború vége felé kapott erőteljes politikai töltetet, de politikai okokból mindkét oldalon egyoldalú értelmezéseket hozott. A megközelítésekben az igen bonyolult valós etnikai viszonyokat leginkább egyszerüsítő és torzító fogalommá a „tiszta etnikai tér” és a „nyelvhatár” vált, amelyek legerőteljesebben a világháború vége felé kedvező politikai helyzetbe került nemzetiségek részéröl váltak hangoztatottá. Így az évek alatt eltűntek az etnikai kapcsolódást és az etnikai sokszínűség kedvező hatásait hangoztató megközelítések. Ezért az etnikai homogenitást erőltető szándék mindkét oldalról a települések etnikai többségét megjelenítő térképekre koncentrált, a nemzetiségek részéről elsősorban azért, mert ezek kapcsán lehetett elfedni más fontos tényeket és 
olyan összefüggő, homogén etnikai területeket bemutatni, amelyekkel indokolhatták területi követeléseiket. Sajnálatos módon (mint hamarosan kiderült), részben kényszerből a magyar politika is ebben látta a területi védekezés lehetőségét, de hiába készített sokkal korrektebb (bár nem teljesen aránytorzítás nélküli) térképeket, ezzel lemondott a népesség nagyságának számszerű, „a települési nyelvhatáron” túli magyar súlyt is kifejező megjelenítéséről, ami elsősorban a közigazgatási kategóriákban és a központokban volt jól kimutatható. Sajnos ez utóbbiak részletes vizsgálata a korszakbeli és a trianoni döntést követő elemzésekből is nagyrészt kimaradtak. Ezért mindenképpen érdemes bemutatni az etnikai tagolódással összefüggő adatok kevésbé ismert jellemzőit is az alábbi néhány pontban.

\section{Statisztikai adatok nem az etnikumokra vagy nemzetiségekre, hanem az anyanyel- vekre vonatkozóan állnak rendelkezésre.}

A Monarchiában a tízévenkénti összeírásokban nem az etnikumra és a nemzetiségre kérdeztek rá, hanem az anyanyelvre és a vallásokra. Mindennek meg voltak az itt most nem részletezhető és a két államrészben részben eltérő politikai okai. Vagyis az etnikai/ nemzetiségi összetételre elsősorban a statisztikában rögzített anyanyelvekböl következtethettek a korszak politikusai, illetve következtethetnek azóta a történészek is. Természetesen nagy lehet az átfedés az anyanyelvi (és részben a vallási) hovatartozás vállalása és a nemzetiségi identitás között, de kétségtelen, hogy magát a következtetést is sokféle politikai cél befolyásolhatja, illetve az adatok feldolgozásának eltérő módszerei is befolyásolhatják az eredményeket.

\section{Egy időben, de külön-külön és eltérő anyanyelvi csoportosítások és kategóriák szerint végezték az osztrák és a magyar népességösszeírásokat.}

Tovább bonyolítja a képet, hogy a két államrészben külön végezték el az összeírásokat, részben eltérő szempontok és csoportosítások alapján, Ausztriában tartományi keretekben, Magyarországon pedig statisztikai régiók szerint, ezeken belül települési, külterületi, járási, megyei szinten, majd ezeket régiós összegzésben is feldolgozták (HILBERT B. 2016). Az 1870-től induló tízévenkénti részletes összeírások tematikailag folyamatosan bővültek, és a népességre vonatkozó összeírási kategóriák is változtak. Fontos megjegyezni, hogy a két államterületen az eltérő etnikai arányok miatt nem azonos anyanyelvi kategóriákban írták össze a népességet. Az osztrák tartományokban a német, cseh és szlovák, lengyel, szlovén, olasz, rutén, szerb és horvát, román és magyar besorolást alkalmazták. Magyarországon pedig hét fő anyanyelv szerint jelenítették meg a népességet: 
magyar, német, tót (szlovák), oláh (román), rutén (ruszin), horvát és szerb. A szlovén, olasz, lengyel, cseh, cigány, bolgár stb. nyelveket az egyéb nyelvek közé sorolták.

\section{Meghatározó német anyanyelvi jelenlét és területileg koncentrálódó anyanyelvek a Monarchiában}

A dualista államban a német és a magyar volt meghatározó helyzetben, de politikai oldalról három anyanyelv tekinthető kiemelt helyzetünek: a német (az osztrák tartományokban), a magyar (Magyar Királyságban) és a horvát (Horvát-Szlavónországban). A legnépesebb német anyanyelv (11 987701 fö) a dualista államon belüli és az osztrák tartományok közötti megoszlásban is jelentős különbséget mutatott. Számukat tekintve legtöbben Alsó-Ausztriában éltek, második helyen pedig Csehországban. Érdemes megjegyezni, hogy a Magyar Királyságban élő német nyelvűek száma magasabb volt, mint egyes osztrák tartományokban, mivel Alsó-Ausztria és Csehország után Magyarország volt a harmadik a német anyanyelvűek számában (CsüLlöG G. 2019).

\begin{tabular}{|l|r|r|r|}
\hline Anyanyelvek & Ausztria & Magyarország & Összesen \\
\hline Német & 9950266 & 2037435 & 11987701 \\
Magyar & 10974 & 10053575 & 10064549 \\
Cseh és szlovák & 6485983 & - & 8453958 \\
\hline Szlovák $^{2}$ & - & 1967975 & - \\
Lengyel $^{6}$ & 4967984 & - & 4967984 \\
Rutén $^{\text {Szerb és horvát' }}{ }^{3}$ & 3518854 & 472587 & 3991441 \\
Szerb $^{4}$ & 783334 & - & 3722967 \\
Horvát $^{5}$ & - & 1106471 & - \\
Román $^{\text {Szlovén }}$ & - & 1833162 & - \\
Olasz $^{8}$ & 275115 & 2949082 & 3224197 \\
Egyéb $^{7}$ & 1252940 & - & 1252940 \\
\hline
\end{tabular}

1. táblázat. Ausztria és Magyarország anyanyelvi tagolódása 1910-ben (fö) a statisztikai összegzésben megnevezett anyanyelvek szerint (forrás: Österreichische Statistik herausgegeben von der K. K. Statistischen Zentralkommission, Neue Folge, 1. Band)

Megjegyzések: ${ }^{1}$ Ausztriában a cseh és szlovák nyelvet közös nyelvként összegezték; ${ }^{2}$ Magyarországon a szlovák nyelvet önálló nyelvként mérték fel, a cseh nyelvet az egyéb kategóriában összegezték; ${ }^{3}$ a szerb és horvát nyelvet közös nyelvként összegezték; ${ }^{4,5}$ Magyarországon a szerb és a horvát nyelvet önálló nyelvekként mérték fel; ${ }^{6}$ Magyarországon a lengyel nyelvet az egyéb kategóriában összegezték; ${ }^{7}$ Magyarországon a szlovén nyelvet az egyéb kategóriában összegezték; ${ }^{8}$ Magyarországon az olasz nyelvet az egyéb kategóriában összegezték. 
Összességében nyolc osztrák tartományban voltak többségben a német anyanyelvűek. Ugyanakkor a német anyanyelv esetében jelentős különbség létezett mind az eredet, mind a kulturális, mind a földrajzi tér vonatkozásában. Bár tágan értelmezve egy nyelv volt, de sok olyan területi, történeti nyelvjárási és identitásbeli eltéréssel, amelyek alapján négy eltérő identitású csoport különíthető el a birodalomban. Az örökös tartományok német anyanyelvü népességének osztrák identitása nagyrészt különbözött a cseh és morva tartományokban élő németekétől, ugyanakkor mind a kettő erős földrajzi és történeti gyökerekkel rendelkezett. Harmadik csoportként az ezekről a területekről a birodalom területén belül elvándorló német nyelvűek jobban megőrizték eredeti identitásukat és a korábbi területekhez való kötődésüket, mint a negyedik csoport, a külső területekről betelepített, főleg bajor és szász eredetű népesség, amely Magyarországon, Galíciában és Bukovinában már sokkal erősebben kötődő helyi identitást alakított ki, elsősorban az ott eltöltött idő hosszúságának függvényében. Tovább bonyolította a helyzetet, hogy a föleg a 19. század közepétől jelentős számban Galíciába és Magyarországra, illetve a Bécsbe és Budapestre bevándorló zsidó népesség jelentős része német nyelvűvé vált.

A dualista állam második legnagyobb számú etnikuma a magyar volt (10 064549 fö), amely a némettel ellentétben koncentráltan a történeti magyar állam területén élt, az osztrák tartományokban és a külső országokban élők száma elhanyagolható volt.

A harmadik legnépesebb etnikum a cseh és szlovák (8 453958 fö) volt. A két nyelv a két állam eltérő összeírási kategóriái alapján összevonva szerepelt az osztrák összeírásban (a morvával együtt), míg a szlovák önállóan a magyar összeírásban (itt a cseh az egyéb nyelvek között szerepelt). Ha külön vesszük azokat, akkor a cseh (és morva) a harmadik legnépesebb (6 485983 fö). A többi osztrák tartományban és Magyarországon már elhanyagolható volt a számuk, elsősorban bizonyos iparterületeken éltek nagyobb koncentrációban. A szlovákok döntő hányada Magyarországon élt.

Nagyságrendben a következő a lengyel volt, majd’ ötmilliós népességszámával, amely lényegében Galíciában koncentrálódott. Hasonló volt a helyzet a rutén népességgel, a közel négymillió föből három és fél millió szintén Galíciában került összeírásra, a kisebb hányaduk pedig Magyarországon. A szerb-horvát népességet együtt számolva Isztriában és Dalmáciában volt többségi anyanyelv. Külön-külön pedig Magyarországon, ahol a horvátok száma meghaladta a szerbekét és döntően Horvát-Szlavónországhoz kötődtek, míg a szerbek megoszlottak az előbbi terület és a délvidéki megyék között. Nagyságrendben a románság következett. Elsősorban Magyarországon éltek, az osztrák tartományok közül csak Bukovinában volt jelentős a számuk. A szlovén népesség száma Ausztriában meghaladta az egymillió föt, elsősorban Krajna és Stájerország között megosztva, de Karintiában, Isztriában, Triesztben és föleg Görz és Gradisča területén is több tízezres volt a számuk (ezt utóbbiban ők voltak többségben). A 10. népességszámú 
anyanyelv az olasz volt, amely legnagyobb számban Tirolban volt jelen.

Érdekesség, hogy a németen kívül nem nagyon volt olyan anyanyelv, amely mind a két államrészben jelentősebb arányban lett volna jelen. Egyedül a horvátok aránya volt jelentősebb Horvát-Szlavónországon kívül két osztrák tartományban, Dalmáciában és a Partvidéken. A szerbek, a szlovének, a rutének és az olaszok száma ebben a vonatkozásban már jóval kisebb volt (1. táblázat). Bonyolultabb kérdés az ausztriai és magyarországi statisztikától külön kezelt, közösen kormányzott Bosznia etnikai megoszlásának aránya, ahol az anyanyelvi tagolódás nem ad pontos képet, elsősorban a vallási tagolódásból lehet az etnikai megoszlásra következtetni. A mintegy 1,9 millió főből nagyjából $42 \%$ volt szerb, $32 \%$ bosnyák és $22 \%$ horvát.

\section{Magyarországon az országos anyanyelvi megoszlás magyar többséget mutat, de a statisztikai régiók közül csak négyben volt magyar többség.}

Az 1910-es adatok alapján az ország egészében a magyar etnikum dominált, bár aránya kis mértékben 50\% alatt maradt, ugyanakkor a Horvát-Szlavónország nélküli területen 54\%-kal többségben volt (2. táblázat). A statisztikai régiók szerinti összegzésben négy régióban volt magyar többség és mindegyikben $50 \%$ felett, kettőben volt román, egyben szlovák, egyben pedig horvát, míg a német, a rutén és a szerb népesség a régiók egyikében sem került többségbe (CsüLlöG G. 2018).

A német nyelv volt egyedül az, amely a magyaron kívül jelentősebb arányban az összes régióban jelen volt (2. táblázat). Az 1. ábra a régiók többségi anyanyelveiről mindenképpen torzít, de azt a fontos tényt jeleníti meg, hogy a Tisza jobb és bal parti régióiban az alacsonyabb térszínek nagyobb népességü településeinek magyar többsége az egész régió anyanyelvi többségére meghatározó volt. A Tisza-Maros köze (a voltaképpeni Bánság) erőteljesen vegyes népességében volt a legalacsonyabb (40\%) egy nyelvnek, ebben az esetben a románnak a többsége (1. ábra).

\section{A megyék mint meghatározó közigazgatási területek anyanyelvi többsége nem mutat összefüggést a magyar „nyelvhatárral”.}

A megyékben létrejött etnikai többségeknek a korszakban meghatározó politikai vetülete volt, mivel a politikai szerveződések a megyei keretekben érvényesültek a legerösebben. A népességre közvetlen hatású hivatalok, intézmények vonzáskörzetei is nagymértékben megyei keretekben vagy azzal átfedésben (pl. bírósági, közjegyzői körzetek) jöttek létre. Ha a megyék többségi etnikumait nézzük, akkor megállapítható, hogy 35 megyében volt valamilyen arányú magyar többség, 14-ben román, 10-ben szlovák, 


\begin{tabular}{|c|c|c|c|c|c|c|c|c|}
\hline Régiók & Magyar & Német & Szlovák & Román & Rutén & Horvát & Szerb & Egyéb \\
\hline $\begin{array}{l}\text { Duna jobb } \\
\text { partja }\end{array}$ & 2221295 & 555694 & 17188 & 833 & 232 & 168436 & 15170 & 105556 \\
\hline $\begin{array}{l}\text { Duna bal } \\
\text { partja }\end{array}$ & 711654 & 144395 & 1279574 & 704 & 898 & 2294 & 200 & 36710 \\
\hline $\begin{array}{l}\text { Duna-Tisza } \\
\text { köze }\end{array}$ & 3061066 & 357822 & 79354 & 4813 & 11721 & 4866 & 154298 & 96318 \\
\hline $\begin{array}{l}\text { Tisza jobb } \\
\text { partja }\end{array}$ & 945990 & 98564 & 441776 & 1910 & 253062 & 486 & 247 & 27646 \\
\hline $\begin{array}{l}\text { A Tisza bal } \\
\text { partja }\end{array}$ & 1604924 & 83229 & 81154 & 621918 & 194504 & 327 & 321 & 8547 \\
\hline $\begin{array}{l}\text { Tisza-Maros } \\
\text { szöge }\end{array}$ & 477988 & 427253 & 44715 & 845850 & 8188 & 4950 & 290434 & 50391 \\
\hline $\begin{array}{l}\text { Király- } \\
\text { hágóntúl }\end{array}$ & 918217 & 234085 & 2404 & 1472021 & 1759 & 523 & 421 & 48937 \\
\hline $\begin{array}{l}\text { Fiume v. és } \\
\text { környéke }\end{array}$ & 6493 & 2315 & 192 & 137 & 11 & 12926 & 425 & 27307 \\
\hline $\begin{array}{l}\text { Horvát- } \\
\text { Szlavónország }\end{array}$ & 105948 & 134078 & 21613 & 846 & 8317 & 1638354 & 644955 & 67843 \\
\hline Összesen (fö) & 10053575 & 2037435 & 1967975 & 2949082 & 472587 & 1833162 & 1106471 & 469255 \\
\hline Összesen (\%) & 48,1 & 9,8 & 9,4 & 14,1 & 2,3 & 8,8 & 5,3 & 2,2 \\
\hline
\end{tabular}

2. táblázat. A Magyar Birodalom népességének anyanyelvi megoszlása statisztikai régiók szerint 1910-ben (fó) a statisztikai összegzésben megnevezett anyanyelvek szerint (forrás: Magyar Királyi Központi Statisztikai Hivatal 1912)

5-ben horvát, 3-ban szerb, 2-ben német, 2-ben rutén, Fiume város és környékén pedig olasz (2. ábra). Ha a többséget három kategóriára bontjuk, akkor látható, hogy a magyar etnikumnak uralkodó, vagyis $75 \%$ feletti többsége 21 megyében volt, a románságnak és a szlovákságnak 4-4 megyében, míg a horvátoknak háromban. A német és a szerb, valamint a rutén etnikum ennél csak kisebb mértékben tudott többségbe kerülni a többi megyében. Összességében mind a hét etnikumnak legalább egy megyében volt többsége (a szerbeknek Torontál vármegyében). A megyék három kategóriára bontott többségi ábrázolása (2. ábra) szerint a magyar többségű megyék messze túlnyúlnak a települési magyar „nyelvhatáron” (Hont, Nógrád, Gömör-Torna, Zemplén, Szatmár és Bihar).

\section{Az anyanyelvek járások szerinti többségének területi megoszlása megközelítő pontossággal mutatja Magyarország összefüggő etnikai tereit.}

A megyéktől eltérően részben más képet mutatnak a járások. A járások anyanyelvi többségét mutató térképen a magyarság jelenléte az ország középső területein összefüggő megjelenésü (3. ábra). A térkép több helyen eltérést mutat a települési nyelvhatártól, több esetben túlnyúlt azon, illetve attól eltérő helyzetben sokkal határozottabb és 


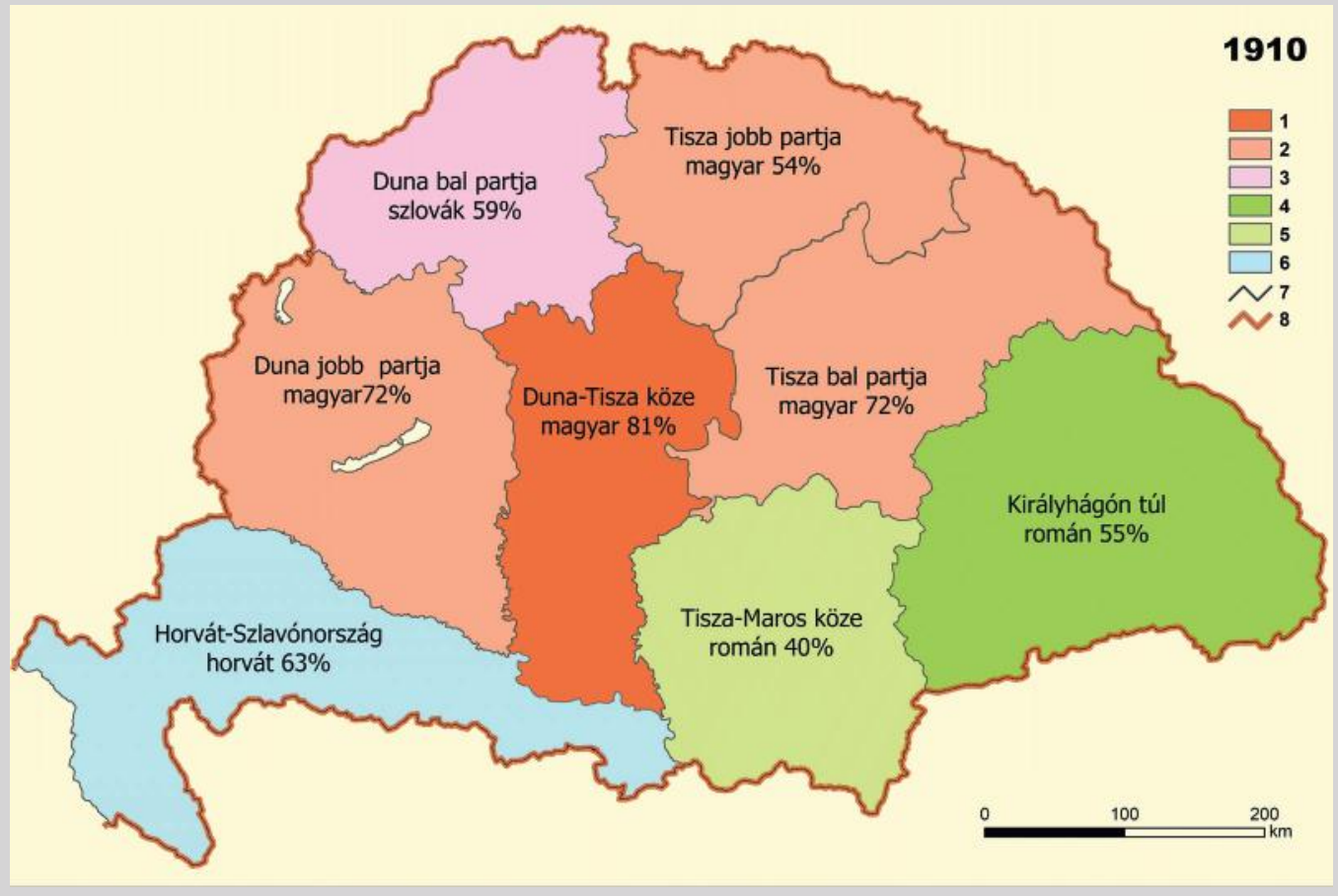

1. ábra. Magyarország statisztikai régióinak többségi anyanyelvei 1910-ben (\%) (szerk. Csüllög G., forrás: Magyar Királyi Központi Statisztikai Hivatal 1912)

Jelmagyarázat: 1. magyar $>75 \%$, 2. magyar 50-75\%, 3. szlovák 50-75\%, 4. román 50-75\%, 5. román $<50 \%$, 6. horvát $50-75 \%$

élesebb elkülönülést mutatott, különösen a szlovák és román etnikumok felé. Ez a területi megoszlás közelebb van a valós területi súly kifejezéséhez, mivel kiegyenlíti mind a megyei, mind a települési megoszlás torzítását.

\section{A központok nagyobb részében kimutatott magyar anyanyelvi többség mutatja a magyar anyanyelvi tér kiterjedését.}

A települési magyar „nyelvhatáron” túlnyúló megyékben a magyar anyanyelvű népesség a nagyobb népességkoncentrációkban volt meghatározó, lényegében az általuk lakott települések sokszor nagyobb népességszámúak voltak, mint a más etnikumok által lakott sok kisebb település. Ebből adódóan egyes megyékben, ahol a települések nagyobb számában volt nem magyar nyelvi többség, a kevesebb településen jelenlévő magyarság a településenkénti 


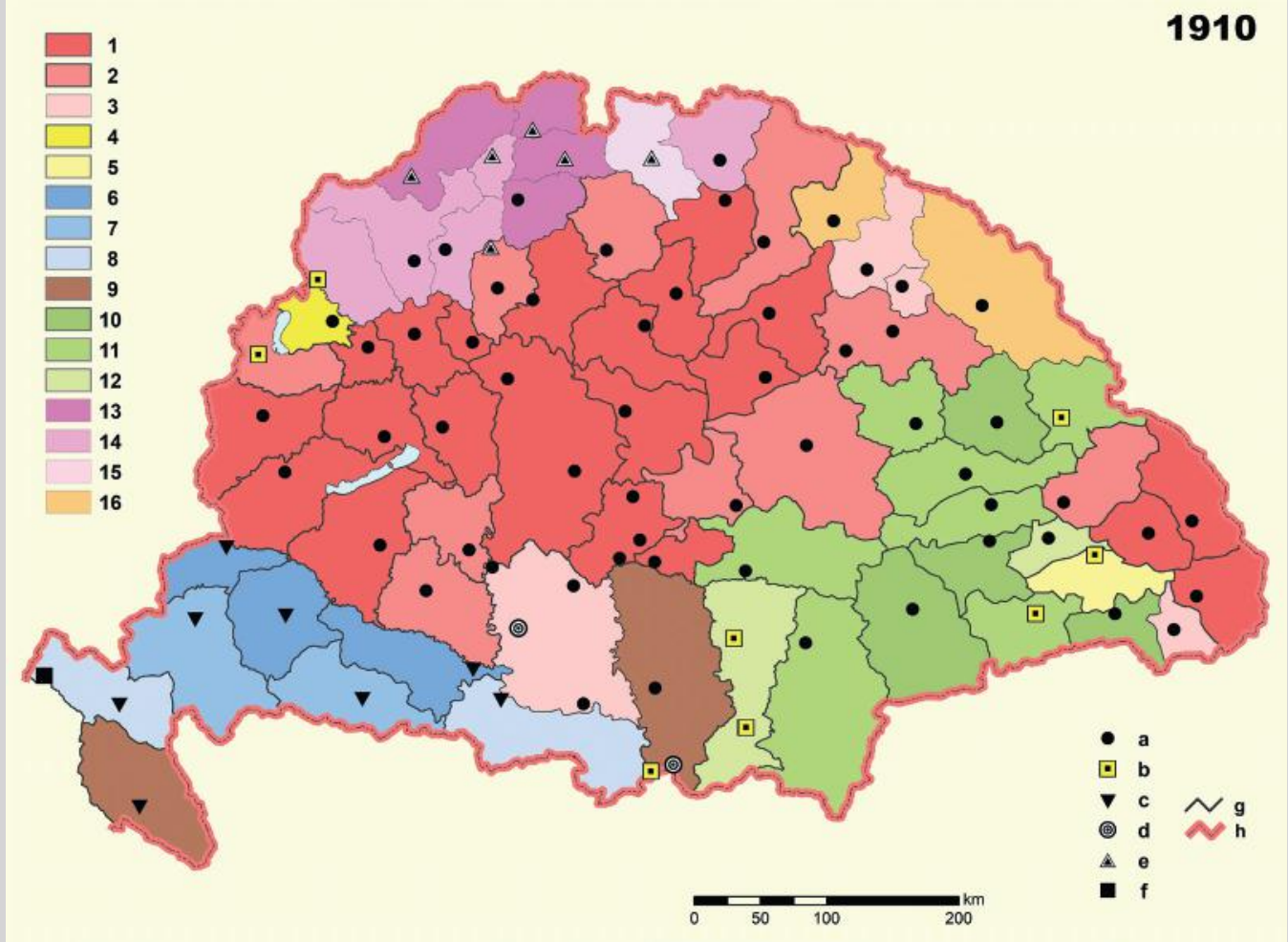

2. ábra. Magyarország megyéinek, megyeszékhelyeinek és törvényhatósági jogú városainak anyanyelvi többsége a statisztikai régióhatárokkal (szerk. Csüllög G., forrás: Magyar Királyi Központi Statisztikai Hivatal 1912)

Jelmagyarázat: megyék: 1. magyar $>75 \%$, 2. magyar 50-75\%, 3. magyar $<50 \%$, 4. német 50-75\%, 5. német $<50 \%$, 6. horvát $>75 \%$, 7. horvát $50-75 \%$, 8 horvát $<50 \%$, 9. szerb $<50 \%$, 10. román $>75 \%$, 11. román $50-75 \%$, 12. román $<50 \%$, 13. szlovák $>75 \%$, 14. szlovák $50-75 \%$, 15. szlovák $<50 \%$, 16. rutén $<50 \%$; városok - a. magyar, b. német, c. horvát, d. szerb, e. szlovák, f. olasz; határok: g. megyehatár, h. országhatár

magasabb népességszáma és egyben koncentráltsága miatt sokkal nagyobb súllyal rendelkezett. Ennek kapcsán tehát a különböző anyanyelvek területi súlyának értelmezéséhez fontos tényező a központok anyanyelvi, etnikai többségének vizsgálata (2. és 3. ábra).

Magyarország 83 központi szerepü településének (megyeszékhelyek és a törvényhatósági jogú városok Budapesttel és Fiumével együtt) jelentős részében (58) a magyar nyelvü népesség volt többségben, a további 25 központból 8 horvát (Horvát-Szlavónországban), 8 német, 6 szlovák, 2 szerb és 1 olasz (Fiume) többségü volt. Ugyanakkor nem volt román és rutén nyelvi többségű központ. A magyar többségű megyeszékhelyek és 


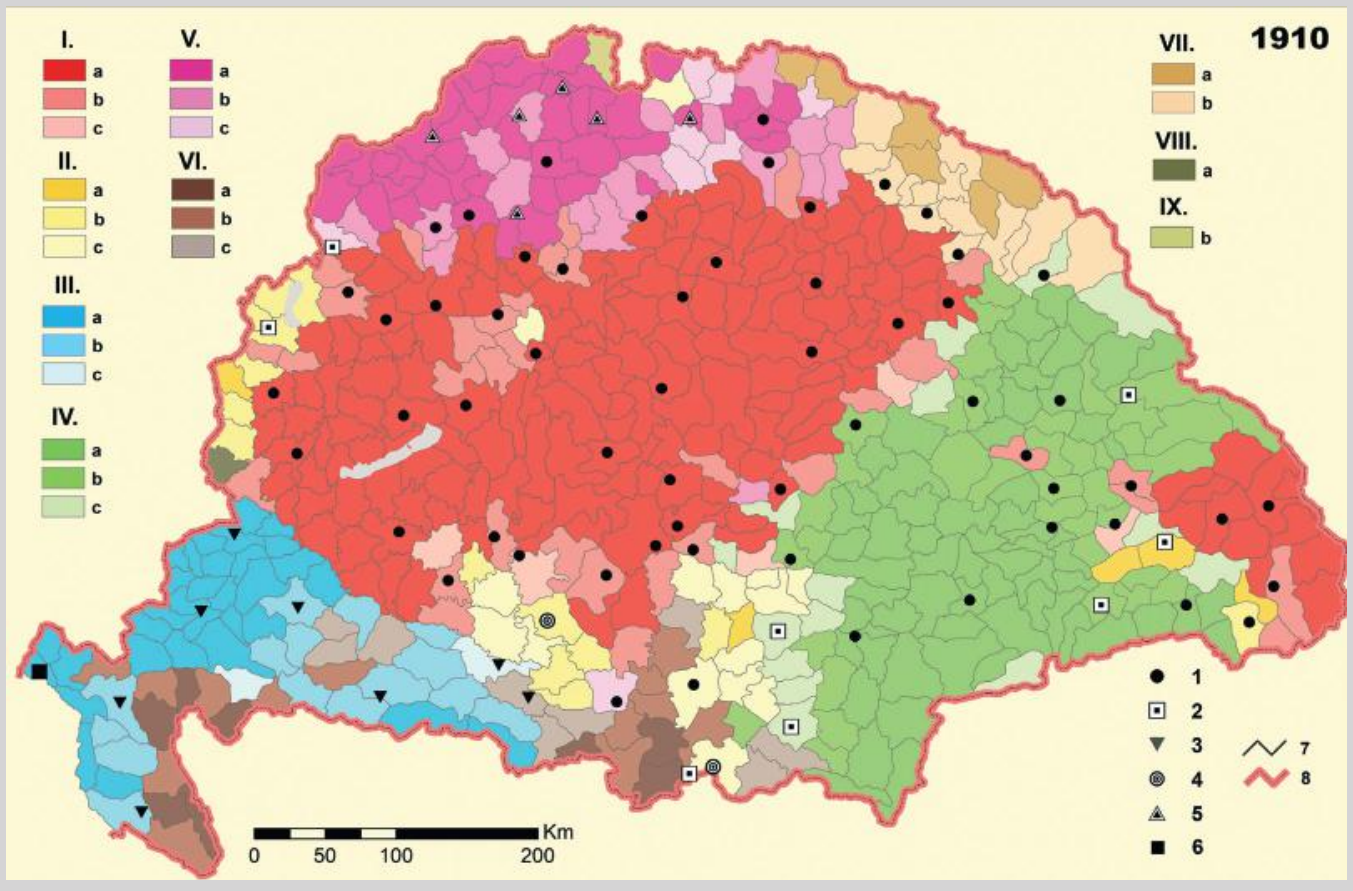

3. ábra. Magyarország járásainak, megyeszékhelyeinek és törvényhatósági jogú városainak anyanyelvi többsége az 1910-es összeírás alapján (szerk. Csüllög G., forrás: Magyar Királyi Központi Statisztikai Hivatal 1912)

Jelmagyarázat: járások: I. - magyar, II. - német, III. - horvát, IV. - román, V. - szlovák, VI. - szerb, VII. - rutén, VIII. - szlovén, IX. - lengyel; arányuk: a. 75\% felett, b. 50-75\% között, c. 50\% alatt; városok: 1. - magyar, 2. - német, 3. - horvát, 4. - szerb, 5. - szlovák, 6. - olasz; határok: 7. - járáshatár, 8. - országhatár

törvényhatósági jogú városok nagyobb része (32) azonban a későbbi trianoni határon kívül helyezkedett el. Különösen érdekes helyzetet jelentett, hogy az erős román többségű erdélyi megyékben 19 magyar többségű központ volt (mellettük 4 német többségü), de egyetlen központban sem volt kimutatható román nyelvű többség. Hasonló volt a helyzet a későbbi Csehszlovákiában, ahol a Felvidéken a magyar nyelvi többségü központok száma (9) meghaladta a szlovákokét (6). Természetesen az alacsonyabb szintü központokban, rendezett tanácsú városokban, járásszékhelyeken már nem volt ilyen kiugró jellegű a különböző nemzetiségi területeken a magyar jelenlét, de egy-két kivételtől eltekintve itt is magasabb volt az arányuk, mint a kisebb, környező településekben. Részben hasonló volt a helyzet több térségben a német nyelv esetében. 
Az urbanizációban megjelent magyar túlsúlyban persze szerepe volt a különböző gazdasági, társadalmi folyamatok által ösztönzött asszimilációnak is (BELuszKy P. 2017a, 2017b). Ugyanakkor ez azt is jelentette, hogy a szlovák és román etnikai térben létező magyar többségü központok aktív vonzásterében az etnikumok között olyan kölcsönös kapcsolatrendszer jött létre, amely jelentős különbségeket generált az ebben érintett és az ebben nem résztvevő szlovák és román etnikumokon belül.

Összességében kijelenthetjük azt, hogy az egyes megyékben és főleg a központokban lévő magyar dominancia alapján a trianoni határmegvonással a magyar etnikai tér vesztesége sokkal nagyobb mértékü volt, mint ahogy azt a nyelvhatárhoz való viszonyítás mutatja.

\section{A trianoni népességvesztésben a magyar „nyelvhatártól” való hátrányos eltéré- sénél sokkal súlyosabb következménnyel járt a valós magyar anyanyelvi tér figyelmen kívül hagyása.}

Az 1910-es összeírások abból a szempontból is fontosak, hogy ezek publikált adatai (föleg a francia nyelvüek) jelentős szerepet kaptak mind a magyarországi román, szerb és szlovák etnikum követeléseinek megfogalmazásában, mind a szerb és a román állam területi követeléseiben, továbbá - és nem utolsósorban - a béketárgyalásokban (Csüllög G. et al. 2020). Ezeket a területszerző államok érdekei szerint elsősorban a települési adatokra építették, így határozva meg a különböző nyelvhatárokat, amelyeket azonban a trianoni határok kijelölésekor - elsősorban a magyar etnikum rovására - már nemigen vettek figyelembe (LőK кÖs J. 2000). Sőt, területszerzési célokból figyelmen kívül hagyták a valós közigazgatási kereteket, azok etnikai arányait, a városok etnikai képét és főleg a térkapcsolatokat, a központok és vonzásterük müködésének folytonosságát. Mindenesetre tény, hogy ennek következményei nemcsak Magyarországot sújtották, hanem az utódállamoknak is több évtizedes (részben a jelenig ható) társadalmi, gazdasági és térszerkezeti problémákat okoztak (Csüllög G. - HoRvátH G. 2020).

\section{ÖSSZEGZÉS}

A fentiek alapján látható, hogy az anyanyelvekre vonatkozó statisztikai adatok alapján mind Ausztriában, mind Magyarországon számos etnikum élt, amelyek között a történeti és részben a dualizmus kori területi folyamatok, migrációk következményeként igen bonyolult etnikai viszonyok jöttek létre. Ugyanakkor a két állam etnikai jellege és így az ebből fakadó problémák sok tekintetben különböztek. Ausztriában föleg a tartományokban jelentkeztek problémák és alapvetően a német-szláv, illetve német-olasz 
ellentétek éleződtek ki a 20. század elejére. Ausztriát elsősorban a tartományok szerint eltérően tömbszerü etnikai területek jellemezték, kevésbé volt jellemző az etnikai terek keveredése, természetesen a 18. századtól a tartományokban jelen voltak és fontos szerepet kaptak a német nyelvűek. De az alapvető problémát a birodalmon belüli történeti államiságra épülő cseh, lengyel és részben olasz törekvések adták.

Magyarország etnikai térbeliségét ezzel szemben olyan sajátos összetettség jellemezte, amelynek alapja volt a fö etnikumok (magyar, horvát, szlovák, román és rutén) tömbszerü megjelenése, de emellett történeti okokból jelentős volt egyes etnikumok (német, magyar, szerb, szlovák) szigetszerű megjelenése is. Többnyire nem voltak éles határok a tömbök érintkezésénél, hanem itt keveredtek egymással a különböző etnikumú települések, sőt sokszor a településeken belül az etnikumok is. Így a magyarországi etnikai térbeliséget nemcsak az ország közepén kialakult jelentős magyar etnikai tömb és az azt körülvevő más etnikumok tömbjei jellemezték, hanem ennek a magyar etnikai tömbnek a széles érintkezési, kevert etnikumú zónája is. Már önmagában ez is (a szigetszerű etnikai jelenlétek mellett) lehetetlenné tett egy igazságos „nyelvhatárra” épülő etnikai térrendezést. További fontos különbség, hogy Ausztriában a nem német etnikumoknak olyan történeti, közigazgatási keretei voltak, mint Csehország, Morvaország és Galícia, ahol a szláv etnikumok többségben voltak. Ezzel szemben Magyarországon 1868 után egyedül Horvát-Szlavónország volt külön jogállású politikai és egyben egy sajátos osztott (horvát-szerb-olasz-szlovén) etnikai tér, míg a német, a szlovák, a román és a szerb etnikum nem kapott összefüggő, nagyobb területi, politikai, közigazgatási keretet. Itt a politikai, gazdasági, társadalmi és ezekkel összefüggően az etnikai folyamatok is jóval kisebb egységekben a megyei, törvényhatósági jogú városi és járási keretekben zajlottak. Az államnyelv erős túlsúlya a közigazgatásban magával hozta a magyar nyelvüek magas számát a különböző központokban, amelyben nagy szerepe volt az állam részéről csak részben szorgalmazott asszimilációnak. Az 1910-es adatokból (2. és 3. ábra) látható, hogy ekkorra kialakult a magyar nyelvi térnek egy sajátos vertikális tagolódása, amely a központok révén ráépült a román, szlovák és rutén etnikai térre.

Mindezek a sajátos etnikai jellegek is szerepet kaptak abban, hogy a Monarchia felbontásakor eltérőképpen kezelték a két államrészt. Ausztriát gyorsabban és határozottabban, kész terv alapján és kevés egymás közötti vitával bontották fel. Azokat az osztrák tartományokat, ahol nem a német nyelv volt többségben és állami múlttal rendelkeztek, a geopolitikai elvek betartásával is le lehetett választani Ausztriától. Ez még Cseh- és Morvaország esetében sem volt támadható, mivel bennük az új államhoz került németség nagy része nem Alsó- és Felső-Ausztriához, hanem inkább a porosz, a szász, illetve a sziléziai németséghez kötődött. Ausztria kapcsán igazán komoly, történeti gyökereket érintő nyelvterületi leválasztás csak Tirolban és Krajna esetében történt. Így 
Ausztriának az „örökös tartományai” esetében sokkal kisebb terület- és népességvesztést kellett megélnie, ami sem területben, sem népességszámban messze nem volt olyan mértékü, mint Magyarországon, ahol csak Horvát-Szlavónországban lehetett egységes etnikai területet elkülöníteni a népesség összetétele és a történetiség alapján.

Magyarország esetében az összetett sajátos etnikai térszerkezet sokféle megközelítést tett lehetővé kinek-kinek az érdeke szerint. Azonban az antanthatalmaknál jelentős hatásuk lett a határok kijelölésére az etnikumok által készített, sokszor féligazságokat mutató etnikai térképeknek, amelyeket a konkrét helyzetekhez alakítva használtak fel. Természetesen ezek valójában csak jól használható indokok voltak a valódi cél, a területszerzés megvalósítására, amelynek az eszköze a „tárgyalásos” katonai megszállás volt, vagyis a demarkációs vonalak folyamatos áthelyezését követö bevonulás. Az etnikai határoktól elszakadó területszerzési cél elérését jól mutatják a véglegesen meghúzott trianoni határok is, aminek következtében elsősorban nem az cáfolta meg az etnikai elv érvényesítését, hogy a magyar „nyelvhatár” jórészt az országhatáron kívülre került, hanem az, hogy számos magyar többségű és nagy népességű központ került az országhatáron túlra, leválasztva a magyar nyelvterületről. A magyar féllel szemben, amely nem igazán értelmezte a központokban lévő etnikai súlyt, a román, szerb és cseh politikusok nagyon is tisztában voltak vele, ezt az is mutatja, hogy már a megszállás kezdetén igyekeztek a központokban a magyar államapparátust kiiktatni és a magyar nyelvűek számát csökkenteni.

Mindezek eredménye lett, hogy a soknemzetiségű birodalom felbontásával kisebb, de ugyanolyan mértékben soknemzetiségü államok jöttek létre, amelyek nem igazán nevezhették volna magukat „nemzetállamnak”. Lényegében „nemzetállamnak” csak Ausztria és Magyarország mondhatta magát, mivel egyedül ezekben alakult ki 90\% körüli többsége az államalkotó etnikumoknak. Így Közép-Európa 1925 utáni képe a 10 évvel azelőtti birodalmak térségéből az egymást sakkban tartó kisállamok térségévé vált, kiszolgáltatva a nagyhatalmak érdekeinek és céljainak. Európa számára nem hozott sok jót a következő évtizedekben, hogy az 1918 és 1923 közötti antantpolitikusok a területi felosztások tárgyalásaiban nem számoltak döntéseik következményeivel, amikor csak az ideológiában hangoztatták az etnikai elveket és valójában teret engedtek a román, szerb és cseh területszerzési törekvéseknek.

\section{IRODALOM}

Beluszky P. (2017a): A városok - olvasztótégelyek? (A [nyelvi] asszimiláció területi vonatkozásai a dualizmus korában I.). - Történeti Földrajzi Közlemények 5. 2. pp. 183-204.

Beluszky P. (2017b): A városok - olvasztótégelyek? (A [nyelvi] asszimiláció területi vonatkozásai a dualizmus korában II.). - Történeti Földrajzi Közlemények 5. 3-4. pp. 183-204. 
CsÜLlöG G. (2018): Magyarország regionális téregységeinek anyanyelvi jellemzői 1910-ben. - In: Pénzes J. (szerk.) Falu - város - periféria: határon innen és túl: Süli-Zakar István professzor emlékére. Didakt Kiadó, Debrecen. pp. 72-79.

CsüLlöG G. (2019): A Monarchia etnikai jellemzői. - In: Gulyás L. (föszerk.): A trianoni békediktátum története hét kötetben. I. Trianon Nagy Háború alatti előzményei, az Osztrák-Magyar Monarchia bukása 1914-1918. VIKEK, Szeged. pp. 80-95.

Csüllög G. - HoRvÁth G. (2020): Geopolitikai elvek Ausztria és Magyarország területi feldarabolása mögött. - Történeti Földrajzi Közlemények 8. 1-2. pp. 28-37.

CsüLlög G. - Gulyás L. - SubA J. (2020): Térképek a trianoni békediktátum történetéhez. - Egyesület Közép-Európa Kutatására, Szeged. 318 p.

Hilbert B. (2016): Ausztria és Magyarország migrációs kapcsolata a dualizmus idején (1870-1910). Földrajzi Közlemények 140. 4. pp. 362-375.

Lőккӧs J. (2000): Trianon számokban. - Püski Kiadó, Budapest. 384 p. 